\title{
Is somatostatin a humoral regulator of the endocrine pancreas and gastric acid secretion in man?
}

\author{
F B LOUd, J J HOLST, E EGENSE, B PETERSEN, AND J CHRISTIANSEN
}

From the Department of Surgery D, Glostrup Hospital, Institute of Medical Physiology C, The Panum Institute, University of Copenhagen, and Department of Clinical Chemistry CL, Rigshospitalet, Copenhagen, Denmark.

SUMMARY The effect of low dose infusions of somatostatin on meal stimulated gastric acid secretion was studied in eight healthy volunteers by intragastric titration after a peptone test meal with radioimmunoassay control of the plasma concentrations of somatostatin and the pancreatic hormones glucagon and insulin. Infusion of somatostatin in a dose of $100 \mathrm{ng} / \mathrm{kg} / \mathrm{h}$, resulting in a plasma concentration of $13 \cdot 4 \pm 2 \cdot 1 \mathrm{pmol} / \mathrm{l}$, inhibited acid secretion significantly, and in a dose of $800 \mathrm{ng} / \mathrm{kg} / \mathrm{h}$, with corresponding plasma concentration of $66 \cdot 5 \pm 12.0 \mathrm{pmol} / \mathrm{l}$ the acid secretion was virtually abolished. Plasma concentrations of insulin and pancreatic glucagon decreased significantly during infusion of $200 \mathrm{ng} / \mathrm{kg} / \mathrm{h}(24.5 \pm 7.5 \mathrm{pmol} / \mathrm{l})$ and glucose concentrations increased. Serum gastrin was only significantly decreased during the highest dose of somatostatin. The range of plasma somatostatin concentrations obtained with the lower doses correspond to reported physiological variations. The results support the concept that somatostatin participates in the hormonal control of the pancreatic endocrine and the acid secretion.

The particular localisation and shape of the somatostatin-producing $\mathrm{D}$-cells in the gastric epithelium and the pancreatic islets suggests that somatostatin acts as a paracrine messenger. ${ }^{1-4}$ Studies in dogs by Schusdziarra $e t a l^{5}$ however, have indicated that somatostatin may act as a true hormone with a regulatory role in the homeostasis of ingested nutrients. Furthermore, studies in different experimental animals ${ }^{6-13}$ and human subjects $^{14-20}$ have shown that exogenous somatostatin is a potent inhibitor of gastric acid secretion and of the endocrine pancreas, and it has been suggested that somatostatin participates in the physiological control of these secretions as a hormonal mediator. ${ }^{50-21}$ The reported effects of somatostatin may be pharmacological, however, because plasma concentrations were generally not controlled.

The present study deals with the effect of increasing doses of somatostatin on meal stimulated gastrin and gastric acid secretion under immunochemical control of the plasma concentrations of somatostatin. In addition we studied the effect on

Address for correspondence: Dr F B Loud. Department of Surgery D. Glostrup Hospital, DK-2600 Glostrup. Denmark.

Received for publication 15 June 1984 the pancreatic hormones glucagon and insulin, the secretion of which under these circumstances is moderately stimulated.

\section{Methods}

SUBJECTS

Eight healthy volunteers, four men and four women, median age 33 years (range 24-44 years) were studied. All gave informed consent. The study was approved by the ethical committee of Copenhagen County.

\section{EXPERIMENTAL PROCEDURE}

Each subject was studied on three separate days. After an overnight fast a Levin tube with a thin welded polyvinyl tube was placed in the stomach under fluoroscopic control. The stomach was emptied. The gastric acid secretion was measured by automatic intragastric titration, using a modification of the method described by Fordtran and Walsh. ${ }^{22}$ A peristaltic pump was used to mix the stomach contents and to aspirate and reinfuse samples of the stomach contents to and from a titration chamber in which the $\mathrm{pH}$-probe was placed. The $\mathrm{pH}$-probe was connected with an autotitrator (Radiometer, Copenhagen) which maintained a constant $\mathrm{pH}$ of $5 \cdot 5$ 
in the stomach by infusing $0.5 \mathrm{~N} \mathrm{NaHCO}_{3}$ to the titration chamber. The cumulative volume of bicarbonate used was recorded on a pen writer. The number of mmoles of sodium bicarbonate required per hour to maintain $\mathrm{pH}$ at 5.5 is equal to the amount of acid secreted (expressed as mmoles $\mathrm{HCl}$ per hour). A test meal, $300 \mathrm{ml}$ of a $10 \%$ peptone solution (Peptone Orthana, Orthana Kemisk Fabrik, Kastrup, Denmark) with $\mathrm{pH} 5.5$ was instilled into the stomach, and infused constantly at a rate of $200 \mathrm{ml} / \mathrm{h}$ via the polyvinyl tube to maintain a constant volume of the test meal in the stomach during the study.

\section{CONTROL STUDY}

On the first day each subject was studied for four hours during intravenous infusion of physiological saline, in order to record the time course of test meal stimulated acid secretion.

\section{SOMATOSTATIN STUDY}

On two separate days each subject was studied for three hours. During the first hour physiological saline was infused intravenously and during the next two hours intravenous infusion of somatostatin in increasing doses was given in random order as shown in the Table.

Somatostatin (synthetic somatostatin, Fluka-AG, Buchs, Switzerland) was dissolved in $1 \mathrm{mmol} / \mathrm{l} \mathrm{HCl}$ and diluted in $0.9 \%$ saline containing $1 \%$ human albumin (Nordisk Albumin, Denmark) and stored at $-20^{\circ} \mathrm{C}$. Before every infusion the solution was subjected to sterile filtration by means of Milliex-GS single use filter, $0.22 \mu \mathrm{m}$ (Millipore, SA, 67 Moijhein, France).

\section{BLOOD SAMPLES}

For analyses of somatostatin, glucose, glucagon, insulin and gastrin blood samples were drawn into chilled tubes containing EDTA and aprotinin (Trasylol, Bayer, GFR $500 \mathrm{KIU} / \mathrm{ml}$ blood) from a cubital vein every 15 minutes throughout the study. The samples were centrifuged immediately after at $4^{\circ} \mathrm{C}$, and plasma stored at $-20^{\circ} \mathrm{C}$ until assay.

Table Somatostatin study. During intragastric titration in eight healthy human subjects somatostatin was given in different, increasing doses as shown below in random order on two separate days

\begin{tabular}{cll}
\hline & \multicolumn{2}{l}{ Intravenous somatostatin $\mu \mathrm{g} / \mathrm{kg} / \mathrm{h}$} \\
\hline Minutes & $\mathrm{A}$ & $\mathrm{B}$ \\
$0-60$ & 0 & 0 \\
$60-120$ & $0 \cdot 1$ & $0 \cdot 2$ \\
$120-180$ & $0 \cdot 4$ & $0 \cdot 8$ \\
\hline
\end{tabular}

LABARATORY ANALYSES

Somatostatin, glucagon, insulin, and gastrin concentrations were measured radioimmunochemically. For somatostatin, antiserum R213, which is directed against the somatostatin sequence 5-10, was used in a previously described radioimmunoassay ${ }^{23} 24$ and for determination of glucagon, the glucagon antiserum 4305, which is directed against the 19-29 sequence of glucagon ${ }^{25}$ was used. The gastrin antiserum used, 2604-8, is highly specific for gastrin and binds the three large molecular forms of gastrin with equimolar potency. ${ }^{26}$ Insulin was determined as described by Albano ${ }^{27}$ and blood-glucose by the hexokinase method. ${ }^{28}$

\section{CALCULATIONS}

Acid secretion during somatostatin infusion, given as meq $\mathrm{H}^{+} / 30 \mathrm{~min}$, is based on the last $30 \mathrm{~min}$ of each infusion period, when the plasma concentration of somatostatin had reached a plateau. For the same reason, all radioimmunoassay results including the somatostatin values are given as the mean of the values from the last $30 \mathrm{~min}$ of each infusion period or, for the control experiment, as the mean of the values from the second and third hour. Statistical evaluation of the data was performed using the Wilcoxon's test for pair differences, if preceding analysis of variance (Friedmans's two-way analysis) allowed rejection of the null-hypothesis.

\section{Results}

The cumulated gastic acid secretion of the control study is shown in Figure 1. The secretory rate was constant throughout the study, even during the fourth hour. The concentration of somatostatin in plasma remained constant throughout the control study (mean value: $5.3 \pm 0.2 \mathrm{pmol} / 1$ ).

The gastric acid secretion during the different somatostatin infusions and corresponding plasma concentrations are shown in Figure 2. A significant inhibition of acid secretion is seen already during infusion of somatostatin in a dose of $100 \mathrm{ng} / \mathrm{kg} / \mathrm{h}$ with corresponding mean plasma concentration of $13 \cdot 4 \pm 2 \cdot 1 \mathrm{pmol} / \mathrm{l}$. During infusion of the highest dose of somatostatin resulting in mean plasma concentrations of $66 \cdot 5 \pm 12 \cdot 0 \mathrm{pmol} / \mathrm{l}$ the gastric acid secretion was nearly abolished.

Plasma insulin concentrations decreased with increasing doses of somatostatin and the same was true for pancreatic glucagon as shown in Figure 3. Significant decreases were observed with doses $>100 \mathrm{ng} / \mathrm{kg} / \mathrm{h}$.

No significant alteration in serum gastrin was seen during the first three doses of somatostatin, but 


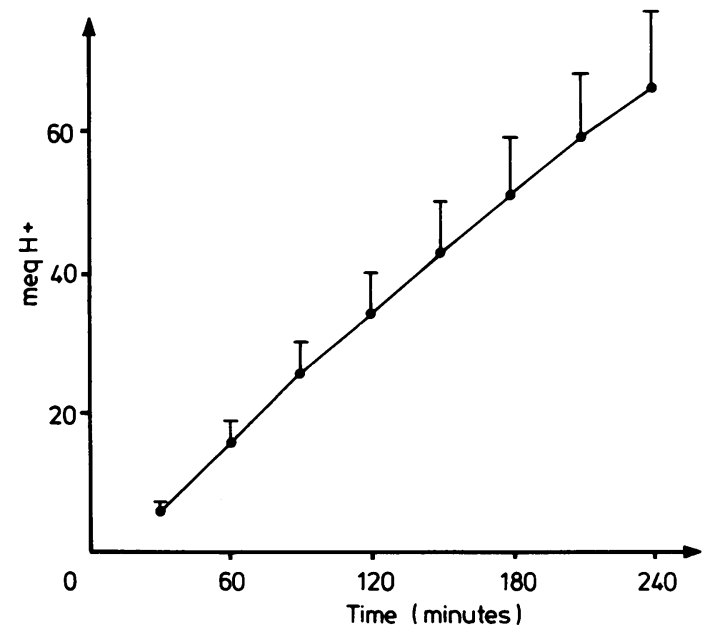

Fig. 1 Control study. Cumulated gastric acid secretion (meq $\mathrm{H}^{+}$) during intragastric titration with a peptone meal.
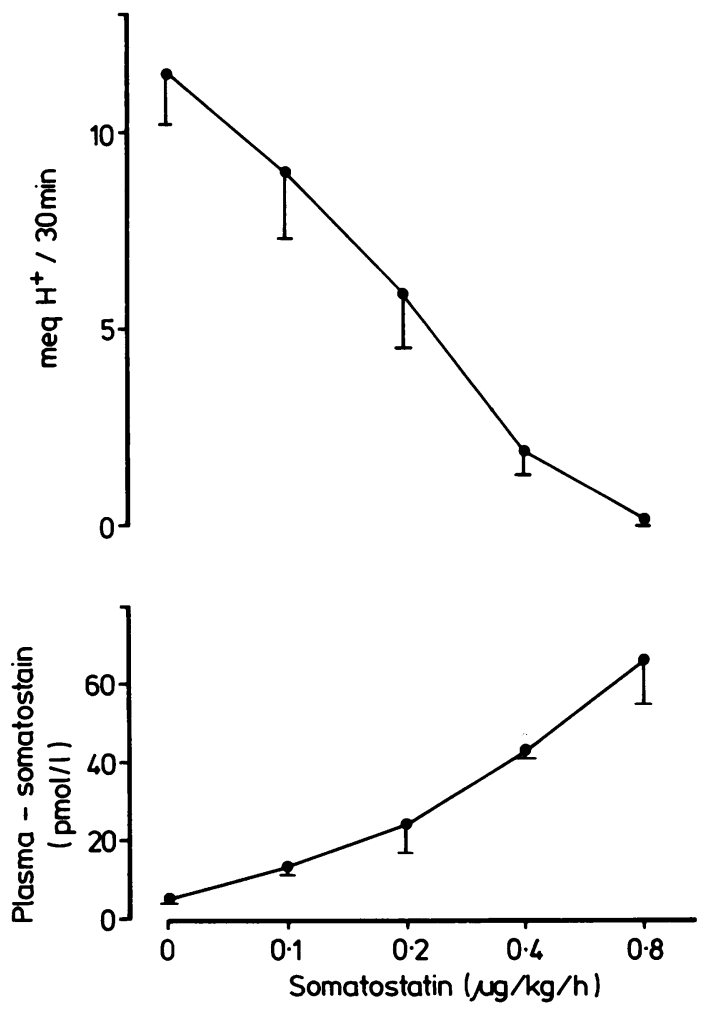

Fig. 2 Gastric acid secretion (meq $\mathrm{H}^{+} / 30$ minutes) and corresponding plasma somatostatin concentrations during intragastric titration and iv infusion of somatostatin in increasing doses $(0 \cdot 1,0 \cdot 2,0 \cdot 4$ and $0 \cdot 8 \mu \mathrm{g} / \mathrm{kg} / \mathrm{h})$ in eight healthy subjects. Mean $\pm S E M$.

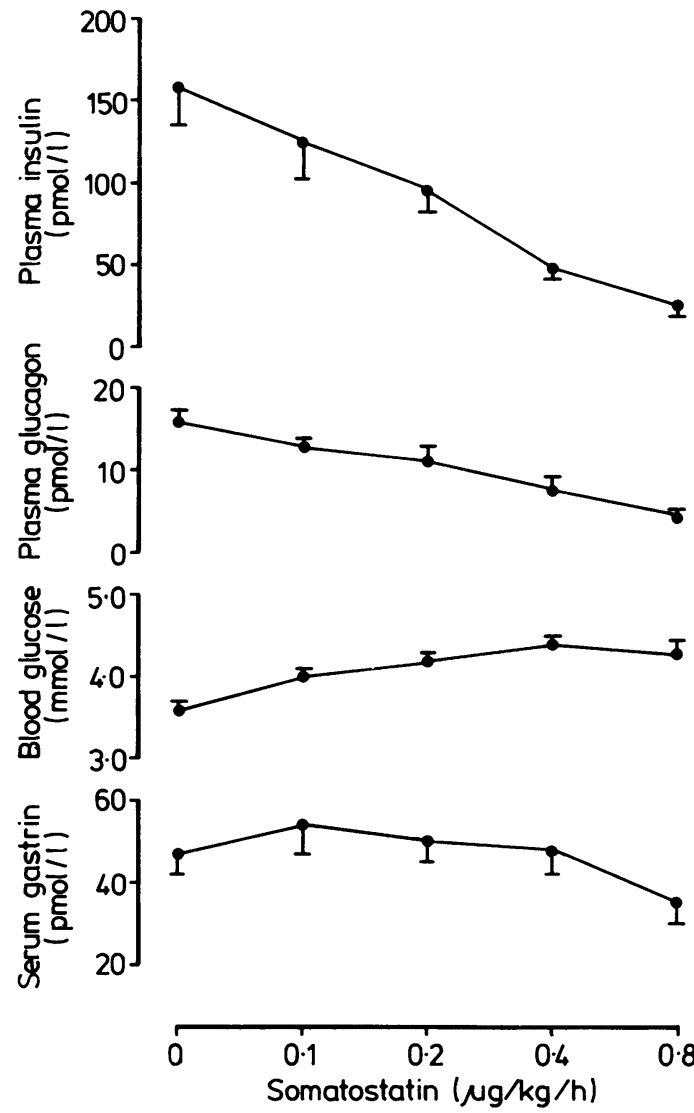

Fig. 3 Plasma insulin, plasma glucagon, blood glucose and serum gastrin during intragastric titration and iv infusion of somatostatin in increasing doses. Mean $\pm S E M$ of the mean values from the last 30 min of each infusion period or, for the control experiment, the mean value from the second and third hour of intragastric titration.

during the highest dose of somatostatin a significant decrease $(p<0.05)$ was noted.

Blood glucose increased significantly $(p<0.01)$ during all somatostatin doses.

\section{Discussion}

The study confirms that exogenous somatostatin is a potent inhibitor of gastric acid secretion in man, ${ }^{15-19}$ and shows that somatostatin inhibits acid secretion in a dose dependent manner. The doses used in the present study are lower than those of previous studies. The minimum dose required for significant inhibition was $100 \mathrm{ng} / \mathrm{kg} / \mathrm{h}$, resulting in a plasma concentration of $13.4 \mathrm{pmol} / \mathrm{l}$. The increase, which is less than $10 \mathrm{pmol} / \mathrm{l}$, may be considered physiological 
because similar increases have been observed in relation to fasting, stress, meal ingestion, hypoglycaemia ${ }^{29-30}$ (Holst et al, unpublished studies of plasma somatostatin responses to starvation, exercise, and mixed meals). The reported increases have been in the order of $10-30 \mathrm{pmol} / \mathrm{l}$, calculated as somatostatin 1-14; in this laboratory, the meal induced increases in normal subjects average 21 $\mathrm{pmol} / \mathrm{l}$. It has been reported that part of the total concentration of somatostatin like immunoreactivity in peripheral plasma is owing to the presence of the 28-amino acid peptide somatostatin $1-28 .^{31}$ Possibly, meal induced increases include this molecular form of somatostatin, too. ${ }^{32}$ Somatostatin $1-28$, however, is also a potent inhibitor of acid secretion..$^{33}$ Our exclusive use of somatostatin 1-14 for infusion should therefore give quantitatively valid results.

Previous findings indicate that somatostatin inhibits gastrin release in animals ${ }^{8-10}$ and in $\operatorname{man}^{14} 151919$ and it has been suggested that the inhibitory effect of somatostatin on gastric acid secretion is caused by inhibition of gastrin release. Jansen and Lamers, ${ }^{19}$ however, found that inhibition of gastrin release by somatostatin could not fully account for the inhibition of bombesin stimulated gastric acid secretion, and Vatn et $a l^{16}$ found no changes in basal plasma gastrin during somatostatin infusion. In the present study there was no correlation between acid inhibition and serum gastrin. Thus low doses of somatostatin inhibits gastric acid secretion without affecting circulating gastrin, suggesting another mode of action, perhaps directly on the parietal cell. ${ }^{35}$

The secretion of the pancreatic hormones insulin and glucagon, estimated on the basis of their peripheral plasma concentration, showed the same sensitivity to somatostatin as gastric acid secretion. Like in the gastric mucosa, somatostatin secreting cells are found locally in the pancreatic islets where they are believed to exert a paracrine control of islet function. ${ }^{1}$ But our results show that circulating somatostatin may very well influence pancreatic endocrine secretion in an endocrine manner. In a recent study ${ }^{20}$ the effects of low doses of somatostatin on the endocrine pancreas were less pronounced than those observed here. Undoubtedly the slight stimulation of the endocrine pancreas caused by the peptone meal administered in the present study facilitated the demonstiation of the inhibitory effect of somatostatin.

The expert technical assistance by Mrs Kirsten Huusfeldt and Mrs Merete Hagerup is gratefully acknowledged. The study was supported by grants from the Danish Medical Research Council.

\section{References}

1 Larsson L-I, Goltermann N, de Magistris L, Rehfeld JF, Schwartz TW. Somatostatin cell processes as pathways for paracrine secretion. Science 1979; 205: 1393-4.

2 Larsson L-I. Peptide secretory pathways in GI-tract.: cytochemical contribution to regulatory physiology of the gut. Am J Physiol 1980; 239: G237-46.

3 Safouri B, Weir G, Bitar K, Maklouf G. Stimulation of gastrin secretion from the perfused rat stomach by somatostatin antiserum. Life Sci 1979; 25: 1749-54.

4 Chiba T, Kadowaki S, Taminato T et al. Effects of anti-somatostatin gamma-globulin on gastrin release in rats. Gastroenterology 1981; 81: 321-6.

5 Schusdziarra V, Zyznar E, Rouiller D et al. Splanchnic somatostatin: a hormonal regulator of nutrient homeostatis. Science 1980; 207: 530-2.

6 Barros D'Sa AAJ, Bloom SR, Baron JH. Direct inhibition of gastric acid by growth hormone release inhibiting hormone in dogs. Lancet 1975; 2: 886-7.

7 Gomez-Pan A. Reed JD, Albinus M et al. Direct inhibition of gastric acid and pepsin secretion by growth hormone release inhibiting hormone in cats. Lancet 1975; 2: 888-90.

8 Konturek SJ, Tasler J, Cieszkowski M, Coy DH, Schally AV. Effect of growth hormone release inhibiting hormone on gastric secretion, muscosal blood flow and serum gastrin. Gastroenterology 1976; 70: 737-41.

9 Barros D'Sa AAJ, Bloom SR, Baron JH. Inhibition by somatostatin (growth hormone release inhibiting hormone, GH-RIH) of gastric acid and pepsin and G-cell release of gastrin. Gut 1978; 19: 315-20.

10 Barbezat GO, Kaplan ER, Bowey FSB, Berelowitz M, Van Hoorh-Hickman R. Kinetics of somatostatin inhibition of pentagastrin stimulated gastric acid secretion. Eur J Pharmacol 1979; 53: 255-9.

11 Thomas WEG. Inhibitory effect of somatostatin on gastric acid secretion and serum gastric in dogs with and without duodenogastric reflux. Gut 1980: 21: 996-1001.

12 Thomas WEG. The kinetics of somatostatin inhibition of gastric acid secretion. Regulat Peptides 1980; 1: 245-51.

13 Shapiro B, Pienta K, Heldsinger A, Vinik AI. Somatostatin is an agonist and noncompetitive antagonist of gastrin in oxyntic cell function. Endocrinology 1981; 109: 1117-21.

14 Bloom SR, Mortimer $\mathrm{CH}$, Thorner $\mathrm{MO}$ et al. Inhibition of gastrin and gastric acid secretion by growth hormone release inhibiting hormone. Lancet 1974; 2: 1106-9.

15 Raptis S, Dollinger HC, von Berger L, Schegel W. Schroder KE, Pfeiffer EF. Effects of somatostatin on gastric secretion and gastrin release in man. Digestion 1975; 13: 15-26.

16 Vatn MH, Schrumpf E, Hanssen KF, Myren J. The effect of somatostatin on pentagastrin stimulated gastric secretion and on plasma gastrin in man. Scand $J$ Gastroenterol 1977; 12: 833-9.

17 Konturek SJ, Swierczek J, Kwiecien N, Mikos E, Oleksy J, Wierzbicki Z. Effect of somatostatin on meal 
induced gastric secretion in duodenal ulcer patients. Dig Dis 1977; 22: 981-8.

18 Schrumpf E, Vatn MH, Hanssen KF, Myren J. A small dose of somatostatin inhibits the pentagastrin stimulated gastric secretion of acid, pepsin and intrinsic factor in man. Clin Endocrinology 1978; 8: 391-5.

19 Jansen JBMJ, Lamers CBHW. The effect of somatostatin on bombesin stimulated serum gastrin and gastric acid secretion in man. Digestion 1981; 21: 193-7.

20 Souquet JC, Rambliere R, Riou JP et al. Hormonal and metabolic effects of near physiological increase of plasma immunoreactive somatostatin 14. J Clin Endocrinol Metab 1983; 56: 1076-9.

21 Bottcher W, Yamada T, Kauffman CL. Somatostatin is an enterogastrone. Gastroenterology 1983; 84: 1112.

22 Fordtran JS, Walsh JH. Gastric acid secretion rate and buffer content of the stomach after eating. J Clin Invest 1973; 52: 642-57.

23 Newgaard CB, Holst JJ. Heterogeneity of somatostatin like immunoreactivity in extracts of porcine, canine and human pancreas. Acta Endocrinol (Copenh) 1981; 98: 564-72.

24 Hilsted L, Holst JJ. On the accuracy of radioimmunological determination of somatostatin in plasma. Regulat Peptides 1983; 4: 13-31.

25 Holst JJ. Evidence that glicentin contains the entire sequence of glucagon. Biochem $J$ 1980; 187: 337-43.

26 Stadil F, Rehfeld JF. Determination of gastrin in serum. Scand J Gastroenterol 1973; 8: 101-109.

27 Albano JDM, Ekins RP, Maritz G, Turner RC. A sensitive, precise radioimmunoassay of serum insulin, relying on charcoal separation of bound and free hormone moieties. Acta Endocrinol (Copenh) 1972; 70: 487-509.

28 Widdonson GM, Penton JR. Determination of serum and plasma glucose on the "auto-analyser II" by use of hexokinase reaction. Clin Chem 1972; 18: 299-300.

29 Arimura A. Recent progress in somatostatin research. Biomed Res 1981; 2: 233-57.

30 Penman E, Wass JA, Medbak S et al. Response of circulating immunoreactive somatostatin to nutritional stimuli in normal subjects. Gastroenterology 1981; 81: 692-9.

31 Baldissera FGA, Munoz-Perez MA, Holst JJ, Somatostatin 1-28 circulates in human plasma. Regulat Peptides 1983; 6: 63-9.

32 Polonsky KS, Shoelson SE, Docherty HM, Plasma somatostatin 28 increases in response to feeding in man. J. Clin Invest 1983; 71: 1514-8.

33 Konturek SJ, Tasler J, Jaworek J et al. Gastrointestinal secretory, motor, circulatory, and metabolic effects of prosomatostatin. Proc Natl Acad Sci USA 1981; 78: 1967-71.

34 Seal A, Yamada T, Debas H, et al. Somatostatin-14 and -28: clearance and potency on gastric functions in dogs. Am J Physiol 1982; 243: G97-G102.

35 Reyl FJ, Lewin MJM. Intracellular receptor for somatostatin in gastric mucosal cells: Decomposition and reconstitution of somatostatin-stimulated phosphoprotein phosphatases. Proc Natl Acad Sci USA 1982; 79: $978-82$. 